\title{
Neutralizing Antibodies and Pathogenesis of Hepatitis C Virus Infection
}

Samira Fafi-Kremer ${ }^{1,2,3}$, Catherine Fauvelle ${ }^{1,2}$, Daniel J. Felmlee ${ }^{1,2}$, Mirjam B. Zeisel ${ }^{1,2}$, Quentin Lepiller $^{1,2,3}$, Isabel Fofana ${ }^{1,2}$, Laura Heydmann ${ }^{1,2}$, Françoise Stoll-Keller ${ }^{1,2,3}$ and Thomas F. Baumert ${ }^{1,2,4, *}$

1 Inserm, U748, Strasbourg, France ; E-Mails: samira.fafi-kremer@unistra.fr (S.F.-K.); catherine.fauvelle@etu.unistra.fr (C.F.); felmlee@unistra.fr (D.J.F.); mirjam.zeisel@unistra.fr (M.B.Z.) ; lepiller@unistra.fr (Q.L.); isabel.fofana@unistra.fr (I.F.); heydmann@unistra.fr (L.H.); francoise.stoll@unistra.fr (F.S.-K.)

2 Université de Strasbourg, Strasbourg, France

3 Laboratoire de Virologie, Hôpitaux Universitaires de Strasbourg, Strasbourg, France

4 Pôle Hépato-digestif, Hôpitaux Universitaires de Strasbourg, Strasbourg, France

* Author to whom correspondence should be addressed; E-Mail: thomas.baumert@unistra.fr; Tel.: +33 3688537 03; Fax: +33368853750.

Received: 2 August 2012; in revised form: 28 September 2012 / Accepted: 28 September 2012 / Published: 9 October 2012

\begin{abstract}
Hepatitis $\mathrm{C}$ virus (HCV) infection is a major cause of chronic liver disease worldwide. The interplay between the virus and host innate and adaptive immune responses determines the outcome of infection. There is increasing evidence that host neutralizing responses play a relevant role in the resulting pathogenesis. Furthermore, viral evasion from host neutralizing antibodies has been revealed to be an important contributor in leading both to viral persistence in acute liver graft infection following liver transplantation, and to chronic viral infection. The development of novel model systems to study HCV entry and neutralization has allowed a detailed understanding of the molecular mechanisms of virus-host interactions during antibody-mediated neutralization. The understanding of these mechanisms will ultimately contribute to the development of novel antiviral preventive strategies for liver graft infection and an urgently needed vaccine. This review summarizes recent concepts of the role of neutralizing antibodies in viral clearance
\end{abstract}


and protection, and highlights consequences of viral escape from neutralizing antibodies in the pathogenesis of HCV infection.

Keywords: antiviral; evasion; liver; transplantation; vaccine

\section{Introduction}

Hepatitis $\mathrm{C}$ virus (HCV) infection is a leading contributor to global chronic liver disease. About 160 million people are currently infected with $\mathrm{HCV}$ ( $\sim 3 \%$ of the world's population), and $\mathrm{HCV}$ is a cause of a third of all deaths from cirrhosis and hepatocellular carcinoma (HCC) [1]. Initial HCV infection is most often followed by chronic hepatitis with persistence of viremia in up to $85 \%$ of individuals [2]. Chronic HCV infection is characterized by variable degrees of hepatic inflammation and fibrosis with an increased risk of progression to cirrhosis and HCC [2]. HCV-related cirrhosis and HCC are leading indications for liver transplantation (LT), representing 20-30\% of adult elective liver transplants performed in Europe and North America [3]. Upon initial infection of the chimpanzee model, HCV RNA levels increase rapidly with a mean doubling time of 12 hours [4]. Thereafter, the viremia increase slows significantly. The innate response of hepatocytes, including interferon I responses, plasmacytoid dendritic cells, and natural killer (NK) cells, contributes to the second phase of slowed viral replication with a mean doubling time of 7.5 days [5]. HCV infection results in a robust innate immunity response including induction of several interferon stimulated genes (ISGs) [6,7]. However, through its structural and non-structural proteins, HCV interferes with innate immunity signaling pathways by interacting with factors that regulate ISGs (core, NS3/NS4A, NS5A), hence attenuating innate responses [8-10].

Aside from mechanisms to escape innate immunity, HCV also employs strategies to escape host adaptive immunity. Adaptive immune responses are mediated by the humoral and cellular immune systems. HCV-specific T lymphocytes are detectable 5 to 9 weeks after infection $[11,12]$ which coincides with the onset of hepatitis. Both $\mathrm{CD} 4+$ and $\mathrm{CD} 8+\mathrm{T}$ cells have been shown to play major roles in the outcome of HCV infection. CD8+ T cells inhibit HCV replication by cytolytic and noncytolytic effector mechanisms [13], which are highly dependent on sufficient CD4+ T-cell cooperation. Indeed, vigorous peripheral and intrahepatic virus-specific $\mathrm{T}$ cell responses that target multiple epitopes have been described in patients who recover from $\mathrm{HCV}$ infection [5,11]. Consistent with these findings, a weak and functionally impaired $\mathrm{T}$ cell response was reported in patients who fail to clear the virus [13]. Viral escape, lack of $\mathrm{CD} 4+\mathrm{T}$-cell cooperation, and regulatory $\mathrm{T}$ cell suppression are all factors that potentially contribute to exhausting $\mathrm{T}$ cell responses in chronically infected patients [13].

In contrast to $\mathrm{T}$ cell responses, humoral responses have long been thought to play a marginal role in the outcome of HCV infection [14]. Unfortunately, studies of host neutralizing responses against HCV have historically been hampered by the lack of a convenient tissue culture system for HCV entry and infection. However, within the last decade, the development of model systems enabling study of HCV entry has significantly advanced our understanding of viral entry and escape. These models have 
reenergized interest in the role of neutralizing antibodies (nAbs) in the pathogenesis of liver disease and their potential in development of antivirals and vaccines.

In this review, we will highlight recent concepts and findings that have revealed the importance of nAbs in $\mathrm{HCV}$ clearance and their impact on $\mathrm{HCV}$ pathogenesis. Furthermore, we will describe mechanisms of viral escape from nAbs.

\section{Neutralizing antibodies and envelope glycoproteins - a moving target}

The antibody response to $\mathrm{HCV}$ in vivo is directed against several viral proteins [14]. However, nAbs that block HCV entry are specifically directed toward the viral envelope, particularly envelope glycoprotein E2. Although the crystal structure of E1-E2 has not been solved, recent findings based on molecular and biochemical analyses provide key information on the structural organization and antigenic determinants of E1 and E2 envelope glycoproteins [15]. The envelope glycoproteins E1 and E2 are type I transmembrane proteins with an N-terminal ectodomain and a short C-terminal transmembrane domain (TMD). The N-terminal ectodomains of E1 and E2 are heavily glycosylated and the glycans are thought to play major roles in E1-E2 folding, HCV entry, and neutralization [16]. Virion-associated E1 and E2 envelope glycoproteins form large covalent complexes stabilized by disulfide bridges [17], forming a functional glycoprotein that mediates viral entry into host cells [17].

Initial HCV attachment to the cell surface is likely facilitated by interaction with attachment factors like glycosaminoglycans [18,19] and probably low-density lipoprotein (LDL) receptor [20], though this internalization pathway might not lead to sustained viral infection [21,22]. Upon initial attachment, at least six host entry factors are important for particle internalization. These include scavenger receptor class B type 1 (SR-BI), CD81, the tight junction proteins claudin 1 (CLDN1) and occludin (OCLN) [23], the receptor tyrosine kinases [24] and the Niemann-Pick C1-like 1 cholesterol absorption receptor [25]. Functional analysis and neutralization experiments using sera from chronically $\mathrm{HCV}$ infected patients have demonstrated that host neutralizing responses target viral entry at a step after initial HCV binding; most likely by interrupting HCV E2-CD81 or HCV E2-SR-BI interactions, or by inhibiting membrane fusion [26]. Indeed, several E2 domains have been shown to play pivotal roles in viral entry and neutralization. Two regions in the E2 envelope glycoprotein have increased genetic variability within a quasispecies and among genotypes and have therefore been identified as hypervariable regions (HVR). The first 27 amino acids of E2 compose the first HVR (HVR1), which plays an important role in viral fitness, likely due to the involvement of SR-BImediated entry [27], assembly, and release of virus particles [28], as well as the HCV membrane fusion process [28]. Although HVR1 is a prime target for neutralizing antibodies, the antibodies that target HVR1 exhibit poor cross-neutralization potency across different $\mathrm{HCV}$ isolates due to the region's high variability [29]. Both deletion of HVR1 and insertion of single mutations in this region significantly increase sensitivity of $\mathrm{HCV}$ variants for neutralization by monoclonal antibodies (mAbs) or patient-derived sera [17,30]. Antibodies that demonstrate broadly neutralizing activity tend to be directed against conserved and conformational epitopes within E2 and most often inhibit the interaction between CD81 and E2 [31-40]. The region located immediately downstream of HVR1 has been shown to contain a potent and highly conserved epitope [41]. This epitope is defined by the mouse mAb AP33 and the rat mAb 3/11. These antibodies inhibit interactions between E2 and either 
CD81 [34] or heparan sulfate [42]. Recently, conformational and widely conserved epitopes were identified in E1 and E2 [38,43-45]. The human mAb AR3, which defines one of these epitopes (aa 396-424; 436-447; 523-540), neutralizes genetically diverse HCV isolates and protects against challenge of heterologous HCV quasispecies in a human liver-chimeric mouse model [38]. Similar antibodies recognizing conformational epitopes, in this case defined by the mouse mAb D32.10 (aa 297-306; 480-494 and 613-621), were observed to circulate at high levels in the sera of patients with resolved HCV infection $[44,45]$.

Recently, epitopes have been identified in the E2 protein at residues 412-426 (epitope I) and 434-446 (epitope II). Interestingly, antibodies that bind one of these epitopes may be interfering antibodies, in that the binding of a non-neutralizing antibody to epitope II disrupts virus neutralization mediated by an antibody binding at epitope I $[46,47]$. However, discrepant data were reported recently by Tarr et al., which indicate that human antibodies that target the aa 434-446 region do not inhibit neutralization but instead are capable of neutralizing HCV pseudoparticles (HCVpp) and cell-culture derived HCV (HCVcc) entry [48].

\section{Humoral responses contribute to control and protection against $\mathrm{HCV}$ infection.}

It has long been known that humoral responses including the generation of neutralizing antibodies are key protective strategies of host immunity. Farci et al. first described neutralizing anti-HCV antibodies in chimpanzees [49]. These antibodies targeted epitopes within the HVR1 of envelope glycoprotein E2 [49]. Interestingly, immunization of chimpanzees with a rabbit serum directed against a synthetic HVR1 peptide protected these animals from viral variants displaying the same HVR1 but not against other viral variants [50].

Two years later, Feray et al. studied retrospectively a cohort of patients who underwent LT due to hepatitis B virus- (HBV) (210/428) or HCV-induced (218/428) liver cirrhosis. Anti-HBV immunoglobulins, which may have incidentally been contaminated with anti-HCV immunoglobulins, were administered to 46 of 218 of the previously HCV-infected patients. Following transplantation, incidence of $\mathrm{HCV}$ viremia was lower in patients receiving immunotherapy (54\%) than in patients whose therapy did not include anti-HCV antibodies (94\%) [51]. Moreover, among the 210 patients who were HCV-negative before LT, acquired HCV infection was less frequently observed in those patients who received immunotherapy than those who did not (26\% vs. $47 \%)$.

These initial observations indicate the potential contribution of neutralizing antibodies in viral control. Subsequently, the use of HCVpp bearing envelope glycoproteins of different genotypes or different patient isolates has allowed more thorough characterization of the role of neutralizing antibodies in both spontaneous control of infection and protection against re-infection.

\subsection{Spontaneous control of HCV infection by humoral immune responses.}

The majority of HCV infections evolve to chronicity; however, a minority of individuals (25-30\%) spontaneously clear HCV infection. Early studies on the role of nAbs in this phenomenon generated controversial results. To address whether $\mathrm{nAb}$ activity associates with immune control of $\mathrm{HCV}$ infection and viral clearance, Logvinoff et al. retrospectively studied the presence of nAbs in plasma samples from seven health care workers who were infected with HCV genotype 1 by needlestick 
exposure. This early study apparently indicated that there may not be a major role for nAbs in spontaneous control of infection since nAbs were detected in two out of seven acutely infected patients and $\mathrm{nAb}$ presence was not associated with viral clearance [52]. Netski et al. reported similar results by examining 12 intravenous drug users whose serum contained only low titers of nAbs restricted to the IgG1 subclass [53]. However, these studies were highly limited by the fact that the viral surrogate ligand was derived from a different isolate than the virus present in the infected patient, thus precluding the detection of isolate-specific antibodies. Later, studies using well-defined nosocomial or single-source HCV outbreaks with a defined inoculum enabled researchers to study the role of isolatespecific nAbs in the control of HCV infection in humans. Using the HCVpp model system, two studies have demonstrated that nAbs are induced in the early phase of infection in patients who subsequently clear the virus [54], or control viral infection [55].

Lavillette et al. studied the kinetics of humoral responses during the acute phase of HCV infection in 17 patients, all of whom had been accidentally infected with the same viral inoculum in a hemodialysis center. All patients were followed-up for six months [55]. While anti-HCV antibodies were detected in all 17 patients, only a fraction of patients (group 1) were characterized by a progressive decrease in viremia finally resulting in a resolution of infection, while this decrease was not observed in other patients (group 2). In vitro neutralization assays demonstrated that only the sera derived from patients of group 1 were able to neutralize HCVpp. These data indicate a correlation between the presence of nAbs during the acute phase of infection and a reduction in viremia [55].

This hypothesis was confirmed and extended by the study of Pestka et al. [54], who studied sera from a cohort of pregnant women whom had been accidentally infected with a single HCV genotype $1 \mathrm{~b}$ inoculum after administration of HCV-contaminated anti-D immunoglobulins in 1978-1979 [54]. Follow-up over 17 years and the use of the HCVpp model system demonstrated that viral clearance was associated with the presence of nAbs during the acute phase of infection. The quantity and efficacy of circulating nAbs diminished over time following viral clearance. In contrast, little to no levels of nAbs were detected during the acute phase in women progressing to chronic infection. Significant antibody titers were subsequently detected in these individuals 10 to 17 years after viral inoculation. These data indicate that a strong and early production of nAbs may contribute to control of the virus during the acute phase of HCV infection and facilitate viral elimination by cellular immune responses. These findings were later corroborated by Dowd et al. who demonstrated that a high concentration of nAbs coincided with viral clearance in individuals who spontaneously resolved HCV infection [56]. Most recently, a detailed immunological study of a single case of spontaneous recovery from chronic HCV infection confirmed the important role of nAbs in HCV clearance [57].

\subsection{Prevention of $H C V$ reinfection by $B$ cell responses.}

In addition to their role in control of infection during the acute phase, nAbs appear to also protect from reinfection. During a monthly follow-up of a high-risk of reinfection group of 22 intravenous drug users who had previously spontaneously cleared HCV infection, 11 individuals were observed to reacquire $\mathrm{HCV}$ infection [58]. Among these patients, 83\% again efficiently spontaneously cleared viral infection. Moreover, the secondary infection in these patients was characterized by reduced viremia relative to the primary infection. In vitro neutralization assays allowed detection of cross-neutralizing 
antibodies in the sera of $60 \%$ of patients who spontaneously cleared infection after reexposure to $\mathrm{HCV}$, while less cross-neutralizing antibodies were detected in the sera of patients who progressed into chronic infection. Spontaneous clearance of HCV reinfection may thus be associated with production of cross-neutralizing humoral responses that are able to decrease or even control viremia (in magnitude and duration) [58]. However, an important caveat in this analysis is the fact that nAbs are not the sole factors involved in protection against reinfection, and this population is likely genetically predisposed to be able to clear $\mathrm{HCV}$ infection. Indeed, a recent study on chimpanzees has demonstrated that a complex network of innate and adaptive immune responses orchestrates protection against reinfection [59].

\section{Implications of viral evasion from neutralizing antibodies in pathogenesis of HCV infection.}

$\mathrm{HCV}$ is able to induce protective nAbs in vivo, yet the reasons why the majority of patients progress to chronic hepatitis are not well-characterized. A major contributor to chronic HCV infection includes the high variability of $\mathrm{HCV}$. Indeed, the virus circulates in the patient as constantly and rapidly evolving genetically distinct, but closely related, variants within the quasispecies. The simultaneous presence of different variants allows the rapid selection of mutants which are best adapted to the host environmental changes, hence the virus could persist in the body despite the presence of neutralizing antibodies. HCV persists via several evasion strategies acting both in the context of chronic infection and in the liver transplant setting.

\subsection{HCV escape and persistence in chronic HCV infection.}

Genetic analysis of the quasispecies variation among patients has demonstrated a correlation between viral clearance and a slowly adapting population. An evolutionarily stable population results in a decreased diversity of HCV variants. On the other hand, chronicity is associated with rapid evolution of the quasispecies, with a multiplicity of variants [60]. Farci et al. demonstrated that the patterns of progression to chronicity were mostly related to the selective pressure put upon the HVR1 region of HCV E2 [60].

The link between viral quasispecies evolution, $\mathrm{nAbs}$, and progression to chronicity has later been confirmed in a chronic HCV patient monitored over a 26-year period [61]. Using the HCVpp system, von Hahn et al. were able to analyze the envelope glycoproteins E1-E2 of quasispecies circulating in this patient at serial time points over 26 years. Neutralization assays using autologous and heterologous sera confirmed that HCV continuously escapes the host's immune system by repeated mutational changes. Generating these mutants results in loss of recognition of the HCV envelope glycoproteins by nAbs [61]. HCV persists by always being a step ahead of host humoral immunity, observed by a lag of the $\mathrm{nAb}$ response behind the rapidly evolving $\mathrm{HCV}$ envelope glycoprotein sequences of the quasispecies population. Consistent with this, a study of eight patients monitored throughout acute infection revealed the same phenomenon in the early stages of infection. Moreover, patients who progressed to chronic infection present low titer of nAbs during early acute phase [56].

The high level of genetic variability of $\mathrm{HCV}$ is able to confer a remarkable viral fitness and adaptation to the host environment through a variety of mechanisms (Figure 1 and reviewed in [62]). 
HCV genetic evolution can result in single point mutations, glycosylation site modifications [63], and conformational changes that could mask envelope glycoprotein binding sites [64-67].

Figure 1. Strategies of viral evasion during Hepatitis $\mathrm{C}$ virus (HCV) infection. HCV has adapted multiple mechanisms to escape host immunity. The low-fidelity HCV RNA polymerase NS5B introduces point mutations to generate a genetic diversity within the quasispecies in an infected host. Many of the viable variants cluster in high-variability regions (e.g., HVR1) of the glycoprotein sequences, which can contribute to differential binding and usage of HDL and SR-BI of different variants, providing flexibility for adaptation against host humoral immunity. Glycosylation sites conceal important functional domains of E2 by forming a glycan shield that reduces the viral immunogenicity and the access of the epitopes to nAbs (reviewed in [68]). Additionally, the action of nAbs may also be disturbed by the presence of interfering antibodies. Another way of escaping neutralizing antibodies is by avoiding the circulation altogether, by dissemination via cellto-cell transmission. HDL: High Density Lipoprotein ; HVR1: Hypervariable Region 1; nAbs: neutralizing Antibodies
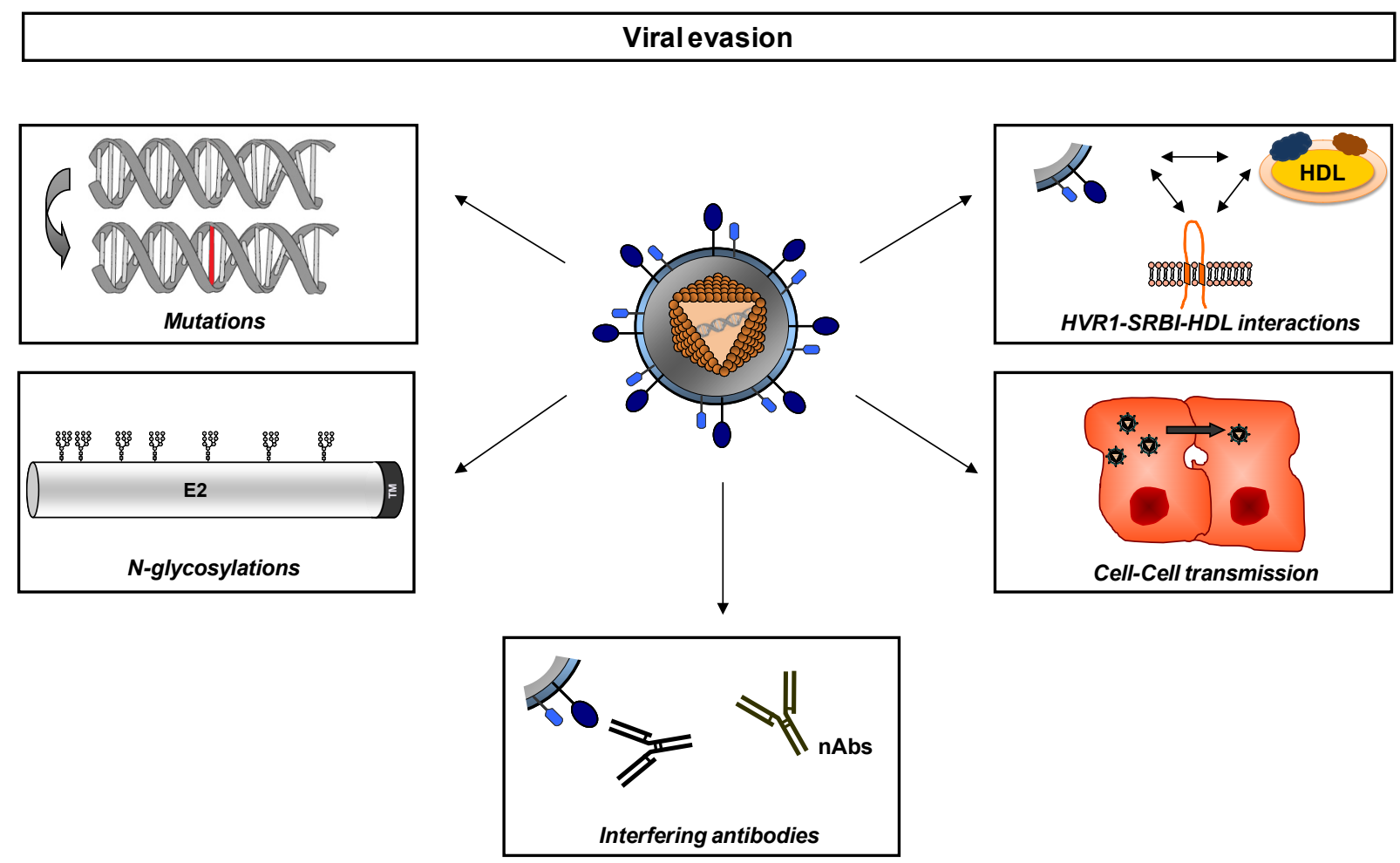

Lipoproteins may also provide protection to $\mathrm{HCV}$ from nAbs, either by masking viral epitopes (by associating with LDL and VLDL) or by accelerating viral entry (HDL), hence limiting exposure of viral epitopes to nAbs [30,62]. Evidence suggests that, at least in genotype 2a variants, those viruses that associate with LDL and VLDL, and are consequently distributed in low-density fractions, are more capable of escape from neutralizing antibodies than higher density viruses [69,70]. In addition to these evasion mechanisms, HCV dissemination by cell-to-cell transmission may also contribute to viral persistence by avoiding surveillance of neutralizing antibodies present in the serum [71,72]. Moreover, 
HCV may directly infect B lymphocytes and induce hypermutations in the heavy chains of immunoglobulins. These hypermutations may decrease the affinity and the specificity of the anti-HCV antibodies allowing the virus to escape from the immune system [73]. Finally, though not a viral strategy, the neutralizing activity of nAbs may incidentally be blocked by interfering antibodies, as previously mentioned $[46,47]$.

\subsection{Escape from B cell responses are a key determinant for liver graft infection.}

HCV escape from nAbs plays a key role not only in viral persistence during chronic HCV infection, but also in de novo infection of the liver graft during LT [74]. Infection of the liver graft occurs within a few hours of graft reperfusion despite the presence of anti-HCV antibodies. Among the diversity of circulating viral variants before transplantation, only a fraction of them persist post-transplantation $[75,76]$. The grafting of the new liver and coinciding initiation of immunosuppressive therapy acts to generate a bottleneck effect that selects the most efficient variants capable of infecting the hepatocytes of the liver graft [74]. Functional analysis using patient-derived HCVpp demonstrated that those HCV variants that infect the liver graft (selected variants) were characterized by markedly enhanced entry compared to variants not present in the post-transplantation setting. Interestingly, persistent variants were only poorly neutralized by antibodies present in pre-transplant serum compared to variants not detected post-transplantation that were efficiently neutralized [74]. These results suggest that escape from neutralizing antibodies and efficient entry into hepatocytes play a major role in reinfection of the liver graft. Interestingly, reverse genetic studies and functional analyses on patient-derived HCVpp and HCVcc identified a novel mechanism of viral evasion during liver transplantation where co-evolution simultaneously occurs between cellular entry factor usage and escape from neutralization. In this study, one of these selected variants harbors mutations (F447, S458 and R478) that modulate CD81dependency of HCV entry, alter E2-CD81 interaction, and mediate escape from antibodies at postbinding steps closely related to HCV-CD81 interactions [77]. Additionally, this study used a large panel of patient-derived antibodies, which demonstrates the functional impact of these mutations in viral persistence in chronic HCV infection [77].

\section{Conclusions and perspectives}

Significant advances have been achieved during the last decade to elucidate the molecular mechanisms of HCV entry and neutralization. The knowledge gained by these studies has renewed enthusiasm in the therapeutic potential of neutralizing antibodies against HCV infection. This potential is bolstered by recent findings that a prime-boost strategy using virus-like particles, pseudotyped for HCV proteins, will trigger broadly neutralizing antibodies in macaques [78]. Furthermore, mAbs can protect against heterologous $\mathrm{HCV}$ quasispecies in a human liver-chimeric mouse model, providing evidence that broadly neutralizing antibodies against $\mathrm{HCV}$ can prevent heterologous $\mathrm{HCV}$ infection $[38,43,79]$. These studies suggest that the development of a prophylactic vaccine against HCV is likely achievable. The resolution of the structure of the HCV envelope glycoproteins and information garnered from high-throughput neutralization screening approaches would contribute in identifying novel viral targets, which in turn promise the development of efficient vaccine strategies. 


\section{Acknowledgments}

The authors thank the European Union (ERC-2008-AdG-233130-HEPCENT and Interreg IV FEDER-Hepato-Regio-Net 2009), the Agence Nationale de Recherches sur le SIDA (ANRS) (2007/306, 2008/354, 2009/183, 2011/132), Hôpitaux Universitaires de Strasbourg (API HUS 2012 / 5256), European Association for Study of the Liver (EASL), and the French National "Investissement d'Avenir" LabEx HEPSYS.

\section{Conflict of Interest}

The authors declare no conflict of interest.

\section{References and Notes}

1. Lavanchy, D. Evolving epidemiology of hepatitis C virus. Clin. Microbiol. Infect 2011, 17, 107-115.

2. Seeff, L.B. Natural history of chronic hepatitis C. Hepatology 2002, 36, S35-46.

3. Muhlberger, N.; Schwarzer, R.; Lettmeier, B.; Sroczynski, G.; Zeuzem, S.; Siebert, U. HCVrelated burden of disease in Europe: a systematic assessment of incidence, prevalence, morbidity, and mortality. BMC Public Health 2009, 9, 34.

4. Dahari, H.; Major, M.; Zhang, X.; Mihalik, K.; Rice, C.M.; Perelson, A.S.; Feinstone, S.M.; Neumann, A.U. Mathematical modeling of primary hepatitis $\mathrm{C}$ infection: noncytolytic clearance and early blockage of virion production. Gastroenterology 2005, 128, 1056-1066.

5. Rehermann, B. Hepatitis $\mathrm{C}$ virus versus innate and adaptive immune responses: a tale of coevolution and coexistence. J. Clin. Invest. 2009, 119, 1745-1754.

6. Marukian, S.; Andrus, L.; Sheahan, T.P.; Jones, C.T.; Charles, E.D.; Ploss, A.; Rice, C.M.; Dustin, L.B. Hepatitis $\mathrm{C}$ virus induces interferon-lambda and interferon-stimulated genes in primary liver cultures. Hepatology 2011, 54, 1913-1923.

7. Thomas, E.; Gonzalez, V.D.; Li, Q.; Modi, A.A.; Chen, W.; Noureddin, M.; Rotman, Y.; Liang, T.J. HCV infection induces a unique hepatic innate immune response associated with robust production of type III interferons. Gastroenterology 2012, 142, 978-988.

8. Ait-Goughoulte, M.; Banerjee, A.; Meyer, K.; Mazumdar, B.; Saito, K.; Ray, R.B.; Ray, R. Hepatitis $\mathrm{C}$ virus core protein interacts with fibrinogen-beta and attenuates cytokine stimulated acute-phase response. Hepatology 2010, 51, 1505-1513.

9. Arnaud, N.; Dabo, S.; Maillard, P.; Budkowska, A.; Kalliampakou, K.I.; Mavromara, P.; Garcin, D.; Hugon, J.; Gatignol, A.; Akazawa, D.; Wakita, T.; Meurs, E.F. Hepatitis C virus controls interferon production through PKR activation. PLoS One 2011, 5, e10575.

10. Polyak, S.J.; Khabar, K.S.; Paschal, D.M.; Ezelle, H.J.; Duverlie, G.; Barber, G.N.; Levy, D.E.; Mukaida, N.; Gretch, D.R. Hepatitis C virus nonstructural 5A protein induces interleukin-8, leading to partial inhibition of the interferon-induced antiviral response. J. Virol. 2001, $75,6095-6106$. 
11. Thimme, R.; Bukh, J.; Spangenberg, H.C.; Wieland, S.; Pemberton, J.; Steiger, C.; Govindarajan, S.; Purcell, R.H.; Chisari, F.V. Viral and immunological determinants of hepatitis C virus clearance, persistence, and disease. Proc. Natl. Acad. Sci. USA 2002, 99, 15661-15668.

12. Cox, A.L.; Mosbruger, T.; Lauer, G.M.; Pardoll, D.; Thomas, D.L.; Ray, S.C. Comprehensive analyses of $\mathrm{CD} 8+\mathrm{T}$ cell responses during longitudinal study of acute human hepatitis $\mathrm{C}$. Hepatology 2005, 42, 104-112.

13. Thimme, R.; Binder, M.; Bartenschlager, R. Failure of innate and adaptive immune responses in controlling hepatitis $\mathrm{C}$ virus infection. FEMS Microbiol. Rev. 2012, 36, 663-683.

14. Chen, M.; Sallberg, M.; Sonnerborg, A.; Weiland, O.; Mattsson, L.; Jin, L.; Birkett, A.; Peterson, D.; Milich, D.R. Limited humoral immunity in hepatitis C virus infection. Gastroenterology 1999, 116, 135-143.

15. Krey, T.; d'Alayer, J.; Kikuti, C.M.; Saulnier, A.; Damier-Piolle, L.; Petitpas, I.; Johansson, D.X.; Tawar, R.G.; Baron, B.; Robert, B.; England, P.; Persson, M.A.; Martin, A.; Rey, F.A. The disulfide bonds in glycoprotein E2 of hepatitis $\mathrm{C}$ virus reveal the tertiary organization of the molecule. PLoS Pathog. 2010, 6, e1000762.

16. Goffard, A.; Callens, N.; Bartosch, B.; Wychowski, C.; Cosset, F.L.; Montpellier, C.; Dubuisson, J. Role of $\mathrm{N}$-linked glycans in the functions of hepatitis $\mathrm{C}$ virus envelope glycoproteins. J. Virol. 2005, 79, 8400-8409.

17. Vieyres, G.; Thomas, X.; Descamps, V.; Duverlie, G.; Patel, A.H.; Dubuisson, J. Characterization of the envelope glycoproteins associated with infectious hepatitis C virus. J. Virol. 2011, 84, 10159-10168.

18. Barth, H.; Schafer, C.; Adah, M.I.; Zhang, F.; Linhardt, R.J.; Toyoda, H.; Kinoshita-Toyoda, A.; Toida, T.; Van Kuppevelt, T.H.; Depla, E.; Von Weizsacker, F.; Blum, H.E.; Baumert, T.F. Cellular binding of hepatitis $\mathrm{C}$ virus envelope glycoprotein E2 requires cell surface heparan sulfate. J. Biol. Chem. 2003, 278, 41003-41012.

19. Koutsoudakis, G.; Kaul, A.; Steinmann, E.; Kallis, S.; Lohmann, V.; Pietschmann, T.; Bartenschlager, R. Characterization of the early steps of hepatitis $\mathrm{C}$ virus infection by using luciferase reporter viruses. J. Virol. 2006, 80, 5308-5320.

20. Molina, S.; Castet, V.; Fournier-Wirth, C.; Pichard-Garcia, L.; Avner, R.; Harats, D.; Roitelman, J.; Barbaras, R.; Graber, P.; Ghersa, P.; Smolarsky, M.; Funaro, A.; Malavasi, F.; Larrey, D.; Coste, J.; Fabre, J.M.; Sa-Cunha, A.; Maurel, P. The low-density lipoprotein receptor plays a role in the infection of primary human hepatocytes by hepatitis C virus. J. Hepatol. 2007, 46, 411-419.

21. Albecka, A.; Belouzard, S.; Op de Beeck, A.; Descamps, V.; Goueslain, L.; Bertrand-Michel, J.; Terce, F.; Duverlie, G.; Rouille, Y.; Dubuisson, J. Role of LDL receptor in the hepatitis c virus life cycle. Hepatology 2011, 998-1007

22. Jiang, J.; Cun, W.; Wu, X.; Shi, Q.; Tang, H.; Luo, G. Hepatitis C virus attachment mediated by apolipoprotein e binding to cell surface heparan sulfate. J. Virol. 2012, 86, 7256-7267.

23. Zeisel, M.B.; Fofana, I.; Fafi-Kremer, S.; Baumert, T.F. Hepatitis C virus entry into hepatocytes: molecular mechanisms and targets for antiviral therapies. J. Hepatol. 2011, 54, 566-576.

24. Lupberger, J.; Zeisel, M.B.; Xiao, F.; Thumann, C.; Fofana, I.; Zona, L.; Davis, C.; Mee, C.J.; Turek, M.; Gorke, S.; Royer, C.; Fischer, B.; Zahid, M.N.; Lavillette, D.; Fresquet, J.; Cosset, F.L.; Rothenberg, S.M.; Pietschmann, T.; Patel, A.H.; Pessaux, P.; Doffoel, M.; Raffelsberger, W.; 
Poch, O.; McKeating, J.A.; Brino, L.; Baumert, T.F. EGFR and EphA2 are host factors for hepatitis $\mathrm{C}$ virus entry and possible targets for antiviral therapy. Nat. Med. 2011, 17, 589-595.

25. Sainz, B., Jr.; Barretto, N.; Martin, D.N.; Hiraga, N.; Imamura, M.; Hussain, S.; Marsh, K.A.; Yu, X.; Chayama, K.; Alrefai, W.A.; Uprichard, S.L. Identification of the Niemann-Pick C1-like 1 cholesterol absorption receptor as a new hepatitis C virus entry factor. Nat. Med. 2012, 18, 281285.

26. Haberstroh, A.; Schnober, E.K.; Zeisel, M.B.; Carolla, P.; Barth, H.; Blum, H.E.; Cosset, F.L.; Koutsoudakis, G.; Bartenschlager, R.; Union, A.; Depla, E.; Owsianka, A.; Patel, A.H.; Schuster, C.; Stoll-Keller, F.; Doffoel, M.; Dreux, M.; Baumert, T.F. Neutralizing host responses in hepatitis $\mathrm{C}$ virus infection target viral entry at postbinding steps and membrane fusion. Gastroenterology 2008, 135, 1719-1728 e1711.

27. Bartosch, B.; Vitelli, A.; Granier, C.; Goujon, C.; Dubuisson, J.; Pascale, S.; Scarselli, E.; Cortese, R.; Nicosia, A.; Cosset, F.L. Cell entry of hepatitis $C$ virus requires a set of co-receptors that include the CD81 tetraspanin and the SR-B1 scavenger receptor. J. Biol. Chem. 2003, 278, 4162441630.

28. Bankwitz, D.; Steinmann, E.; Bitzegeio, J.; Ciesek, S.; Friesland, M.; Herrmann, E.; Zeisel, M.B.; Baumert, T.F.; Keck, Z.Y.; Foung, S.K.; Pecheur, E.I.; Pietschmann, T. Hepatitis C virus hypervariable region 1 modulates receptor interactions, conceals the CD81 binding site, and protects conserved neutralizing epitopes. J. Virol. 2010, 84, 5751-5763.

29. Wang, Y.; Keck, Z.Y.; Foung, S.K. Neutralizing antibody response to hepatitis C virus. Viruses 2011, 3, 2127-2145.

30. Bartosch, B.; Verney, G.; Dreux, M.; Donot, P.; Morice, Y.; Penin, F.; Pawlotsky, J.M.; Lavillette, D.; Cosset, F.L. An interplay between hypervariable region 1 of the hepatitis C virus E2 glycoprotein, the scavenger receptor BI, and high-density lipoprotein promotes both enhancement of infection and protection against neutralizing antibodies. J. Virol. 2005, 79, 8217-8229.

31. Clayton, R.F.; Owsianka, A.; Aitken, J.; Graham, S.; Bhella, D.; Patel, A.H. Analysis of antigenicity and topology of E2 glycoprotein present on recombinant hepatitis $\mathrm{C}$ virus-like particles. J. Virol. 2002, 76, 7672-7682.

32. Hsu, M.; Zhang, J.; Flint, M.; Logvinoff, C.; Cheng-Mayer, C.; Rice, C.M.; McKeating, J.A. Hepatitis $\mathrm{C}$ virus glycoproteins mediate $\mathrm{pH}$-dependent cell entry of pseudotyped retroviral particles. Proc. Natl. Acad. Sci. USA 2003, 100, 7271-7276.

33. Triyatni, M.; Vergalla, J.; Davis, A.R.; Hadlock, K.G.; Foung, S.K.; Liang, T.J. Structural features of envelope proteins on hepatitis $\mathrm{C}$ virus-like particles as determined by anti-envelope monoclonal antibodies and CD81 binding. Virology 2002, 298, 124-132.

34. Owsianka, A.; Clayton, R.F.; Loomis-Price, L.D.; McKeating, J.A.; Patel, A.H. Functional analysis of hepatitis $\mathrm{C}$ virus E2 glycoproteins and virus-like particles reveals structural dissimilarities between different forms of E2. J. Gen. Virol. 2001, 82, 1877-1883.

35. Keck, Z.Y.; Li, T.K.; Xia, J.; Gal-Tanamy, M.; Olson, O.; Li, S.H.; Patel, A.H.; Ball, J.K.; Lemon, S.M.; Foung, S.K. Definition of a conserved immunodominant domain on hepatitis C virus E2 glycoprotein by neutralizing human monoclonal antibodies. J. Virol. 2008, 82, 6061-6066. 
36. Keck, Z.Y.; Op De Beeck, A.; Hadlock, K.G.; Xia, J.; Li, T.K.; Dubuisson, J.; Foung, S.K. Hepatitis C virus E2 has three immunogenic domains containing conformational epitopes with distinct properties and biological functions. J. Virol. 2004, 78, 9224-9232.

37. Habersetzer, F.; Fournillier, A.; Dubuisson, J.; Rosa, D.; Abrignani, S.; Wychowski, C.; Nakano, I.; Trepo, C.; Desgranges, C.; Inchauspe, G. Characterization of human monoclonal antibodies specific to the hepatitis $\mathrm{C}$ virus glycoprotein $\mathrm{E} 2$ with in vitro binding neutralization properties. Virology 1998, 249, 32-41.

38. Law, M.; Maruyama, T.; Lewis, J.; Giang, E.; Tarr, A.W.; Stamataki, Z.; Gastaminza, P.; Chisari, F.V.; Jones, I.M.; Fox, R.I.; Ball, J.K.; McKeating, J.A.; Kneteman, N.M.; Burton, D.R. Broadly neutralizing antibodies protect against hepatitis $\mathrm{C}$ virus quasispecies challenge. Nat. Med. 2008, 14, 25-27.

39. Perotti, M.; Mancini, N.; Diotti, R.A.; Tarr, A.W.; Ball, J.K.; Owsianka, A.; Adair, R.; Patel, A.H.; Clementi, M.; Burioni, R. Identification of a broadly cross-reacting and neutralizing human monoclonal antibody directed against the hepatitis C virus E2 protein. J. Virol. 2008, 82, 10471052.

40. Flint, M.; Maidens, C.; Loomis-Price, L.D.; Shotton, C.; Dubuisson, J.; Monk, P.; Higginbottom, A.; Levy, S.; McKeating, J.A. Characterization of hepatitis C virus E2 glycoprotein interaction with a putative cellular receptor, CD81. J. Virol. 1999, 73, 6235-6244.

41. Dhillon, S.; Witteveldt, J.; Gatherer, D.; Owsianka, A.M.; Zeisel, M.B.; Zahid, M.N.; Rychlowska, M.; Foung, S.K.; Baumert, T.F.; Angus, A.G.; Patel, A.H. Mutations within a conserved region of the hepatitis $\mathrm{C}$ virus $\mathrm{E} 2$ glycoprotein that influence virus-receptor interactions and sensitivity to neutralizing antibodies. J. Virol. 2010, 84, 5494-5507.

42. Barth, H.; Liang, T.J.; Baumert, T.F. Hepatitis C virus entry: molecular biology and clinical implications. Hepatology 2006, 44, 527-535.

43. Giang, E.; Dorner, M.; Prentoe, J.C.; Dreux, M.; Evans, M.J.; Bukh, J.; Rice, C.M.; Ploss, A.; Burton, D.R.; Law, M. Human broadly neutralizing antibodies to the envelope glycoprotein complex of hepatitis C virus. Proc. Natl. Acad. Sci. USA 2012, 109, 6205-6210.

44. Ndongo, N.; Berthillon, P.; Pradat, P.; Vieux, C.; Bordes, I.; Berby, F.; Maynard, M.; Zoulim, F.; Trepo, C.; Petit, M.A. Association of anti-E1E2 antibodies with spontaneous recovery or sustained viral response to therapy in patients infected with hepatitis C virus. Hepatology 2010, 52, 15311542.

45. Petit, M.A.; Jolivet-Reynaud, C.; Peronnet, E.; Michal, Y.; Trepo, C. Mapping of a conformational epitope shared between E1 and E2 on the serum-derived human hepatitis C virus envelope. J. Biol. Chem. 2003, 278, 44385-44392.

46. Zhang, P.; Wu, C.G.; Mihalik, K.; Virata-Theimer, M.L.; Yu, M.Y.; Alter, H.J.; Feinstone, S.M. Hepatitis $\mathrm{C}$ virus epitope-specific neutralizing antibodies in Igs prepared from human plasma. Proc. Natl. Acad. Sci. USA 2007, 104, 8449-8454.

47. Zhang, P.; Zhong, L.; Struble, E.B.; Watanabe, H.; Kachko, A.; Mihalik, K.; Virata-Theimer, M.L.; Alter, H.J.; Feinstone, S.; Major, M. Depletion of interfering antibodies in chronic hepatitis $\mathrm{C}$ patients and vaccinated chimpanzees reveals broad cross-genotype neutralizing activity. Proc. Natl. Acad. Sci. USA 2009, 106, 7537-7541. 
48. Tarr, A.W.; Urbanowicz, R.A.; Jayaraj, D.; Brown, R.J.; McKeating, J.A.; Irving, W.L.; Ball, J.K. Naturally occurring antibodies that recognize linear epitopes in the amino terminus of the hepatitis $\mathrm{C}$ virus e2 protein confer noninterfering, additive neutralization. J. Virol. 2012, 86, 2739-2749.

49. Farci, P.; Alter, H.J.; Wong, D.C.; Miller, R.H.; Govindarajan, S.; Engle, R.; Shapiro, M.; Purcell, R.H. Prevention of hepatitis $\mathrm{C}$ virus infection in chimpanzees after antibody-mediated in vitro neutralization. Proc. Natl. Acad. Sci. USA 1994, 91, 7792-7796.

50. Farci, P.; Shimoda, A.; Wong, D.; Cabezon, T.; De Gioannis, D.; Strazzera, A.; Shimizu, Y.; Shapiro, M.; Alter, H.J.; Purcell, R.H. Prevention of hepatitis C virus infection in chimpanzees by hyperimmune serum against the hypervariable region 1 of the envelope 2 protein. Proc. Natl. Acad. Sci. USA 1996, 93, 15394-15399.

51. Feray, C.; Gigou, M.; Samuel, D.; Ducot, B.; Maisonneuve, P.; Reynes, M.; Bismuth, A.; Bismuth, $\mathrm{H}$. Incidence of hepatitis $\mathrm{C}$ in patients receiving different preparations of hepatitis $\mathrm{B}$ immunoglobulins after liver transplantation. Ann. Intern. Med. 1998, 128, 810-816.

52. Logvinoff, C.; Major, M.E.; Oldach, D.; Heyward, S.; Talal, A.; Balfe, P.; Feinstone, S.M.; Alter, H.; Rice, C.M.; McKeating, J.A. Neutralizing antibody response during acute and chronic hepatitis C virus infection. Proc. Natl. Acad.Sci. USA 2004, 101, 10149-10154.

53. Netski, D.M.; Mosbruger, T.; Depla, E.; Maertens, G.; Ray, S.C.; Hamilton, R.G.; Roundtree, S.; Thomas, D.L.; McKeating, J.; Cox, A. Humoral immune response in acute hepatitis $\mathrm{C}$ virus infection. Clin. Infect. Dis. 2005, 41, 667-675.

54. Pestka, J.M.; Zeisel, M.B.; Blaser, E.; Schurmann, P.; Bartosch, B.; Cosset, F.L.; Patel, A.H.; Meisel, H.; Baumert, J.; Viazov, S.; Rispeter, K.; Blum, H.E.; Roggendorf, M.; Baumert, T.F. Rapid induction of virus-neutralizing antibodies and viral clearance in a single-source outbreak of hepatitis C. Proc. Natl. Acad. Sci. USA 2007, 104, 6025-6030.

55. Lavillette, D.; Morice, Y.; Germanidis, G.; Donot, P.; Soulier, A.; Pagkalos, E.; Sakellariou, G.; Intrator, L.; Bartosch, B.; Pawlotsky, J.M.; Cosset, F.L. Human serum facilitates hepatitis C virus infection, and neutralizing responses inversely correlate with viral replication kinetics at the acute phase of hepatitis C virus infection. J. Virol. 2005, 79, 6023-6034.

56. Dowd, K.A.; Netski, D.M.; Wang, X.H.; Cox, A.L.; Ray, S.C. Selection pressure from neutralizing antibodies drives sequence evolution during acute infection with hepatitis $\mathrm{C}$ virus. Gastroenterology 2009, 136, 2377-2386.

57. Raghuraman, S.; Park, H.; Osburn, W.O.; Winkelstein, E.; Edlin, B.R.; Rehermann, B. Spontaneous clearance of chronic hepatitis $\mathrm{C}$ virus infection is associated with appearance of neutralizing antibodies and reversal of T-cell exhaustion. J. Infect. Dis. 2012, 205, 763-771.

58. Osburn, W.O.; Fisher, B.E.; Dowd, K.A.; Urban, G.; Liu, L.; Ray, S.C.; Thomas, D.L.; Cox, A.L. Spontaneous control of primary hepatitis $\mathrm{C}$ virus infection and immunity against persistent reinfection. Gastroenterology 2010, 138, 315-324.

59. Barth, H.; Rybczynska, J.; Patient, R.; Choi, Y.; Sapp, R.K.; Baumert, T.F.; Krawczynski, K.; Liang, T.J. Both innate and adaptive immunity mediate protective immunity against hepatitis $\mathrm{C}$ virus infection in chimpanzees. Hepatology 2011, 54, 1135-48.

60. Farci, P.; Shimoda, A.; Coiana, A.; Diaz, G.; Peddis, G.; Melpolder, J.C.; Strazzera, A.; Chien, D.Y.; Munoz, S.J.; Balestrieri, A.; Purcell, R.H.; Alter, H.J. The outcome of acute hepatitis C predicted by the evolution of the viral quasispecies. Science 2000, 288, 339-344. 
61. von Hahn, T.; Yoon, J.C.; Alter, H.; Rice, C.M.; Rehermann, B.; Balfe, P.; McKeating, J.A. Hepatitis $\mathrm{C}$ virus continuously escapes from neutralizing antibody and T-cell responses during chronic infection in vivo. Gastroenterology 2007, 132, 667-678.

62. Di Lorenzo, C.; Angus, A.G.; Patel, A.H. Hepatitis C virus evasion mechanisms from neutralizing antibodies. Viruses 2011, 3, 2280-2300.

63. Helle, F.; Vieyres, G.; Elkrief, L.; Popescu, C.I.; Wychowski, C.; Descamps, V.; Castelain, S.; Roingeard, P.; Duverlie, G.; Dubuisson, J. Role of N-linked glycans in the functions of hepatitis C virus envelope proteins incorporated into infectious virions. J. Virol. 2010, 84, 11905-11915.

64. Falkowska, E.; Kajumo, F.; Garcia, E.; Reinus, J.; Dragic, T. Hepatitis C virus envelope glycoprotein E2 glycans modulate entry, CD81 binding, and neutralization. J. Virol. 2007, 81, 8072-8079.

65. Wei, X.; Decker, J.M.; Wang, S.; Hui, H.; Kappes, J.C.; Wu, X.; Salazar-Gonzalez, J.F.; Salazar, M.G.; Kilby, J.M.; Saag, M.S.; Komarova, N.L.; Nowak, M.A.; Hahn, B.H.; Kwong, P.D.; Shaw, G.M. Antibody neutralization and escape by HIV-1. Nature 2003, 422, 307-312.

66. Kwong, P.D.; Doyle, M.L.; Casper, D.J.; Cicala, C.; Leavitt, S.A.; Majeed, S.; Steenbeke, T.D.; Venturi, M.; Chaiken, I.; Fung, M.; Katinger, H.; Parren, P.W.; Robinson, J.; Van Ryk, D.; Wang, L.; Burton, D.R.; Freire, E.; Wyatt, R.; Sodroski, J.; Hendrickson, W.A.; Arthos, J. HIV-1 evades antibody-mediated neutralization through conformational masking of receptor-binding sites. Nature 2002, 420, 678-682.

67. Srivastava, I.K.; Ulmer, J.B.; Barnett, S.W. Role of neutralizing antibodies in protective immunity against HIV. Hum. Vaccin. 2005, 1, 45-60.

68. Helle, F.; Duverlie, G.; Dubuisson, J. The hepatitis C virus glycan shield and evasion of the humoral immune response. Viruses 2011, 3, 1909-1932.

69. Grove, J.; Nielsen, S.; Zhong, J.; Bassendine, M.F.; Drummer, H.E.; Balfe, P.; McKeating, J.A. Identification of a residue in hepatitis $\mathrm{C}$ virus $\mathrm{E} 2$ glycoprotein that determines scavenger receptor BI and CD81 receptor dependency and sensitivity to neutralizing antibodies. J. Virol. 2008, 82, 12020-12029.

70. Prentoe, J.; Jensen, T.B.; Meuleman, P.; Serre, S.B.; Scheel, T.K.; Leroux-Roels, G.; Gottwein, J.M.; Bukh, J. Hypervariable region 1 differentially impacts viability of hepatitis $\mathrm{C}$ virus strains of genotypes 1 to 6 and impairs virus neutralization. J. Virol. 2011, 85, 2224-2234.

71. Timpe, J.M.; Stamataki, Z.; Jennings, A.; Hu, K.; Farquhar, M.J.; Harris, H.J.; Schwarz, A.; Desombere, I.; Roels, G.L.; Balfe, P.; McKeating, J.A. Hepatitis C virus cell-cell transmission in hepatoma cells in the presence of neutralizing antibodies. Hepatology 2008, 47, 17-24.

72. Brimacombe, C.L.; Grove, J.; Meredith, L.W.; Hu, K.; Syder, A.J.; Flores, M.V.; Timpe, J.M.; Krieger, S.E.; Baumert, T.F.; Tellinghuisen, T.L.; Wong-Staal, F.; Balfe, P.; McKeating, J.A. Neutralizing antibody-resistant hepatitis C virus cell-to-cell transmission. J. Virol. 2011, 85, 596605.

73. Machida, K.; Kondo, Y.; Huang, J.Y.; Chen, Y.C.; Cheng, K.T.; Keck, Z.; Foung, S.; Dubuisson, J.; Sung, V.M.; Lai, M.M. Hepatitis C virus (HCV)-induced immunoglobulin hypermutation reduces the affinity and neutralizing activities of antibodies against HCV envelope protein. $J$. Virol. 2008, 82, 6711-6720. 
74. Fafi-Kremer, S.; Fofana, I.; Soulier, E.; Carolla, P.; Meuleman, P.; Leroux-Roels, G.; Patel, A.H.; Cosset, F.L.; Pessaux, P.; Doffoel, M.; Wolf, P.; Stoll-Keller, F.; Baumert, T.F. Viral entry and escape from antibody-mediated neutralization influence hepatitis $\mathrm{C}$ virus reinfection in liver transplantation. J. Exp. Med. 2010, 207, 2019-2031.

75. Hughes, M.G., Jr.; Chong, T.W.; Smith, R.L.; Evans, H.L.; Iezzoni, J.C.; Sawyer, R.G.; Rudy, C.K.; Pruett, T.L. HCV infection of the transplanted liver: changing CD81 and HVR1 variants immediately after liver transplantation. Am. J. Transplant. 2005, 5, 2504-2513.

76. Schvoerer, E.; Soulier, E.; Royer, C.; Renaudin, A.C.; Thumann, C.; Fafi-Kremer, S.; Brignon, N.; Doridot, S.; Meyer, N.; Pinson, P.; Ellero, B.; Woehl-Jaegle, M.L.; Meyer, C.; Wolf, P.; Zachary, P.; Baumert, T.; Stoll-Keller, F. Early evolution of hepatitis C virus (HCV) quasispecies after liver transplant for HCV-related disease. J. Infect. Dis. 2007, 196, 528-536.

77. Fofana, I.; Fafi-Kremer, S.; Carolla, P.; Fauvelle, C.; Zahid, M.N.; Turek, M.; Heydmann, L.; Cury, K.; Hayer, J.; Combet, C.; Cosset, F.L.; Pietschmann, T.; Hiet, M.S.; Bartenschlager, R.; Habersetzer, F.; Doffoel, M.; Keck, Z.Y.; Foung, S.K.; Zeisel, M.B.; Stoll-Keller, F.; Baumert, T.F. Mutations that alter use of hepatitis $\mathrm{C}$ virus cell entry factors mediate escape from neutralizing antibodies. Gastroenterology 2012, 143, 223-233 e229.

78. Garrone, P.; Fluckiger, A.C.; Mangeot, P.E.; Gauthier, E.; Dupeyrot-Lacas, P.; Mancip, J.; Cangialosi, A.; Du Chene, I.; Legrand, R.; Mangeot, I.; Lavillette, D.; Bellier, B.; Cosset, F.L.; Tangy, F.; Klatzmann, D.; Dalba, C. A prime-boost strategy using virus-like particles pseudotyped for HCV proteins triggers broadly neutralizing antibodies in macaques. Sci. Transl. Med. 2011, 3, 94ra71.

79. Dorner, M.; Horwitz, J.A.; Robbins, J.B.; Barry, W.T.; Feng, Q.; Mu, K.; Jones, C.T.; Schoggins, J.W.; Catanese, M.T.; Burton, D.R.; Law, M.; Rice, C.M.; Ploss, A. A genetically humanized mouse model for hepatitis C virus infection. Nature 2011, 474, 208-211.

(C) 2012 by the authors; licensee MDPI, Basel, Switzerland. This article is an open access article distributed under the terms and conditions of the Creative Commons Attribution license (http://creativecommons.org/licenses/by/3.0/). 